\title{
PENGARUH LEVEL PUPUK N,P,K TERHADAP KOMPONEN TANAMAN BRACHIARIA HUMIDICOLA CV.TULLY DAN PENNISETUM PURPUREUM CV.MOTT DI AREAL PERTANAMAN KELAPA
}

\section{Dewi Turangan, Charles.L.Kaunang, Agnitje Rumambi, dan Rustandi}

Fakultas Peternakan Universitas Sam Ratulangi Manado 95115 e-mail :turangandewi@gmail.com

\begin{abstract}
ABSTRAK
Lahan yang ada di bawah pertanaman kelapa dapat dimanfaatkan atau ditanami berbagai komoditi pertanian, termasuk hijauan pakan. Pakan berperan penting dalam keberhasilan suatu usaha peternakan. Produktivitas hijauan perlu ditingkatkan dengan didukung oleh lingkungan fisik tanah dan iklim yang ideal. Permasalahannya, lahan dibawah pertanaman kelapa mempunyai tingkat kesuburan tanah yang rendah (marginal), sehingga salah satu alternatif yang dilakukan adalah dengan jalan pemupukan. Tujuan penelitian ini adalah untuk mengetahui pengharuh kombinasi level pupuk NPK terhadap komponen tanaman Brachiaria humidicola cv.Tully dan Pennisetum purpurteum dwarf di areal pertanaman kelapa. Penelitian ini telah dilaksanakan di Kecamatan Malalayang 1 Barat lingkungan 1 Kota Manado. Metode yang dilakukan secara faktorial pada rancangan dasar acak lengkap (RAL), dengan 4 ulangan. Hasil penelitian menunjukkan bahwa pemupukan unsur makro NPK secara lengkap dibutuhkan untuk meningkatkan komponen daun hijauan pakan untuk memenuhi kebutuhan ternak ruminan.
\end{abstract}

Sebaliknya, komponen batang pada kedua jenis rumput mengalami penurunan dengan semakin lengkap kombinasi pemupukan unsur makro NPK. Hasil analisis statistik menunjukkan bahwa komponen daun rumput Pennisetum pupureum $153.87 \mathrm{Gr} /$ petak nyata lebih tinggi $(\mathrm{P}<0.05)$ dibandingkan dengan Brachiaria humidicola. Sedangkan, komponen batang tidak berbeda nyata untuk kedua jenis rumput. Kesimpulannya, kedua jenis rumput uji membutuhkan perlakuan unsur makro NPK lengkap untuk mendapatkan hasil dengan komponen daun lebih tinggi.

Kata Kunci : Lahan, Hijauan, Pupuk NPK, areal kelapa.

\section{ABSTRACT}

EFFECT OF N,P,K FERTILIZER LEVELS ON PLANT COMPONENTS OF BRACHIARIA HUMIDICOLA CV.TULLY AND PENNISETUM PURPUREUM CV.MOTT IN COCONUT PLANTATIONS. In North Sulawesi there are vast grasslands as pastures so that breeders only utilize the existing land in the coconut plantations as cattle raising area. Existing land under the 
coconut plantation can be utilized or planted variety of agricultural commodities, including forage, where feed was instrumental in the success of animal farm. In increasing the productivity of forage among others, animal grass needs to be supported by the physical environment, ideal soil and climate. The problem in this research was the area under coconut cultivation had low soil fertility (marginal), so one alternative was given by way of fertilization. Therefore the NPK fertilization is one of the most alternative method to overcome the low soil fertility. The objective of this study was to determine the effect of the combination of NPK fertilizer levels on plant components of Brachiaria humidicola $c v$. Tully and Pennisetum purpureum cv.mott in coconut plantations. This research was conducted in the western districts of Malalayang 1, Manado city from October 2013 - February 2014. Factorial design method was performed on the basis of completely randomized design with 4 replications. The result in this study showed that the influence of fertilization was demonstrated for the macro elements NPK fertilization required to increase the component of leaves. These elements were met the needs of forage for ruminants. Otherwise the rod components of both grass types were decreased by more complete combination of macro elements of NPK fertilization. In term of different types of grass, the statistical analysis showed that the leaves of the grass component of Pennisetum purpureum were $153.87 \mathrm{~g} / \mathrm{plot}$, significantly higher $(\mathrm{P}<0.05)$ than Brachiaria humidicola. The stem components were not significantly different for both types of grass. Therefore, the results of this study showed that both types of grass treatment elements required the complete NPK macro to get result with higher leaf components.

\section{Keywords: Land, Forage, NPK Fertilizer, coconut plantation area}

\section{PENDAHULUAN}

Peningkatan produksi ternak ruminansia harus ditunjang dengan tersedianya hijauan yang cukup dan berkualitas sebagai makanan pokok. Rumput Brachiaria humidicola dan Pennisetum purpureum $c v$. Mott merupakan rumput tropis yang tumbuh dengan baik diareal pertanaman kelapa (Whiteman, 2001). Rumput Brachiaria humidicola memiliki komposisi kimia, bahan kering 321,3 g/kg berat segar. Kandungan nutrisi lainnya yang dinyatakan dalam bahan kering adalah bahan organik. Analisis proksimat rumput Pennisetum purpureum cv. Mott dari hasil panen yang diadakan secara teratur berkisar antara $89,66 \%$ protein kasar, BETN 41,34\%, serat kasar 30,86\%, lemak 2,24\%, abu 15,96\% dan TDN mencapai $51 \%$ (Whiteman, 2001). 
Kesuburan tanah adalah salah satu faktor yang dapat menunjang hasil yang Ketersediaan unsur hara didalam tanah dapat dilakukan dengan pemberian pupuk. Besarnya jumlah pupuk yang diberikan tergantung respons dari tanaman pakan tersebut. Semakin lengkap unsur hara yang diberikan dengan jumlah yang tepat, semakin baik dan maksimal hasil yang diperoleh (Polakitan dan Kairupan, 2010).

Unsur hara Nitrogen (N), Fosfor (P), dan Kalium (K), merupakan unsur hara makro yang sangat dibutuhkan untuk pertumbuhan tanaman (Gillen and Ewing, 1992). Nitrogen merupakan faktor pembatas utama karena sering defisien di lahan sebab sifatnya mudah larut, mudah tercuci dan mudah menguap (Aryanto dan Polakitan, 2009). Selanjutnya, unsur Fosfor dan Kalium juga dibutuhkan untuk pertumbuhan tanaman terutama pada pasture yang terintegrasi dengan tanaman kelapa, mengingat kelapa sebagai komoditi utama yang membutuhkan kedua jenis unsur hara ini dalam jumlah yang banyak (Warembourg and Esterlrich, 2000).

Sulawesi Utara adalah salah satu daerah yang tidak terdapat pastura sehingga petani/peternak hanya memanfaatkan lahan yang ada diareal pertanaman kelapa untuk pemeliharaan ternak. Permasalahannya, lahan di bawah pertanaman kelapa mempunyai tingkat baik dari hijauan pakan (Anis, 2011). kesuburan tanah yang rendah (marginal), sehingga salah satu alternatif yang perlu dilakukan adalah dengan jalan pemupukan. Pemupukan bertujuan untuk mengganti unsusr hara yang hilang waktu panen atau terjadi degradasi dari tanah oleh air hujan. Oleh sebab itu, pemupukan NPK merupakan salah satu alternatif yang paling memungkinkan untuk mengatasi tingkat kesuburan tanah yang rendah (marginal). Penelitian ini bertujuan untuk mengetahui pengaruh level pupuk NPK terhadap komponen tanaman Brachiaria humidicola c. Tully dan Pennisetum purpureum dwarf di areal pertanaman kelapa.

\section{MATERI DAN METODE PENELITIAN}

Penelitian ini telah dilaksanakan di Kecamatan Malalayang 1 Barat lingkungan 1 Kota Manado, berlangsung sejak bulan Oktober 2013 - Februari 2014. Bahan penelitian yang digunakan adalah bibit tanaman rumput Brachiaria humidicola dan bibit rumput Pennisetum purpureum cv. Mott dalam bentuk anakan. Pupuk nitrogen $(\mathrm{N})$ dalam bentuk urea, pupuk fosfor (P) dalam bentuk TSP dan pupuk kalium (K) dalam bentuk KCL. Sedangkan peralatan yang digunakan 
adalah cangkul, parang, pisau, gunting, timbangan, amplop ukuran besar, dan alat tulis-menulis.

kandungan bahan kering dan persentasi komponen dari kedua rumput uji. Perlakuan di atas secara faktorial pada rancangan dasar acak lengkap (RAL), dengan 4 ulangan. Perlakuan yang diuji dalam penelitian ini adalah :

Jenis rumput sebagai faktor A :

$\mathrm{a}_{1}=$ Brachiaria humidicola cv. Tully

$\mathrm{a}_{2}=$ Pennisetum purpureum cv. Mott

dan kombinasi sebagai unsur makro faktor B :

$\mathrm{b}_{1}=\mathrm{N}$

$\mathrm{b}_{2}=\mathrm{NP}$

$\mathrm{b}_{3}=\mathrm{NPK}$

Perlakuan diatur secara faktorial $2 \times 3$ dengan rancangan dasar acak lengkap (RAL) dengan 4 ulangan.

Prosedur kerja dalam penelitian ini

: (1) Persiapan lahan; lahan yang digunakan keseluruhan 50x50 meter atau sekitar $2.500 \mathrm{~m}^{2}$. Lahan dibersihkan dari gulma, kemudian untuk mendapatkan keseragaman kondisi tanah dilakukan dengan cara membongkar tanah, digaruk untuk didapatkan partikel tanah yang lebih kecil kemudian diratakan. Lahan dibiarkan selama tiga minggu sampai semua gulma bertumbuh dan disemprot dengan herbisida; (2) Pembuatan petak percobaan; Setelah lahan bersih dari gulma
Penelitian ini dirancang untuk mengetahui pengaruh kombinasi pemupukan N,P,dan $\mathrm{K}$ terhadap selanjutnya dibuat bedeng seluas $2,5 \times 2,5$ meter. (3) Pemupukan; Sesuai dosis yang ditetapkan maka jumlah pupuk Fosfor/petak sebanyak 101,89 gr, sedangkan pupuk Kalium sebanyak 78,116 gr dan pupuk Nitrogen yang digunakan sebanyak 203,804 gram/petak.

Variabel; Variabel yang diukur dalam penelitian ini adalah kandungan bahan kering dan persentasi komponen rumput.

\section{HASIL DAN PEMBAHASAN}

Pengaruh perlakuan pemupukan terhadap hasil bahan kering daun dan batang rumput uji disajikan pada Tabel 1 .

Hasil analisis statistik menunjukkan tidak ada pengaruh interaksi dari perlakuan yang nyata terhadap hasil bahan kering daun dan batang rumput uji. Pengaruh perlakuan pupuk menunjukkan perbedaan nyata $(\mathrm{P}<0.05)$ terhadap hasil bahan kering daun dan batang (Tabel 1). Data menunjukkan bahwa komponen daun dari kedua jenis rumput uji meningkat dengan nyata. Komponen daun tertinggi diperoleh pada kombinasi lengkap NPK pada rumput Brachiaria humidicola sebanyak 223,67 Gr/petak nyata $(\mathrm{P}<0.05)$ lebih tinggi dibandingkan dengan perlakuan pemupukan lainnya (Manske 
dan Caesar-TonThat, 2002). Hal yang sama diperoleh pada komponen daun rumput Pennisetum purpureum cv. Mott sebanyak 196.26 Gr/petak dan nyata Tabel 1. Pengaruh perlakuan pupuk terhadap hasil bahan kering daun dan batang

\begin{tabular}{ccccc}
\hline Perlakuan Pupuk & \multicolumn{2}{c}{ Brachiaria humidicola } & \multicolumn{2}{c}{ Pennisetum purpureum } \\
\cline { 2 - 5 } & Daun & Batang & Daun & Batang \\
\hline N & $179.61^{\mathrm{b}}$ & $191.01^{\mathrm{a}}$ & $118.78^{\mathrm{C}}$ & $198.91^{\mathrm{a}}$ \\
\hline $\mathrm{NP}$ & $188.77^{\mathrm{b}}$ & $194.17^{\mathrm{a}}$ & $146.58^{\mathrm{b}}$ & $180.82^{\mathrm{b}}$ \\
\hline NPK & $223.67^{\mathrm{a}}$ & $176.27^{\mathrm{b}}$ & $196.26^{\mathrm{a}}$ & $179.90^{\mathrm{b}}$
\end{tabular}

Ket: Huruf berbeda pada lajur yang sama beda nyata $(\mathrm{P}<0.05)$

meningkatkan komponen daun yang lebih banyak pada hijauan pakan untuk memenuhi kebutuhan ternak ruminant (Kaligis dan Sumolang, 1990).

Hasil penelitian menunjukkan komponen batang pada kedua jenis rumput mengalami penurunan dengan semakin lengkap kombinasi pemupukan unsur makro NPK (Kaligis dan Sumolang, 1990). Hasil analisis statistik menunjukkan bahwa komponen batang terendah pada rumput Brachiaria humidicola sebanyak 176,27 Gr/petak nyata lebih rendah $(\mathrm{P}<0.05)$ dibandingkan dengan perlakuan
$(\mathrm{P}<0.05)$ lebih tinggi dari perlakuan pemupukan lainnya. Data ini menunjukkan bahwa pemupukan unsur makro NPK secara lengkap dibutuhkan untuk 
Ket: Huruf yang berbeda pada lajur yang sama berbeda nyata $(\mathrm{P}<0.05)$

Hasil analisis statistik menunjukkan bahwa komponen daun rumput Pennisetum pupureum $153.87 \mathrm{Gr} /$ petak nyata lebih tinggi $(\mathrm{P}<0.05)$ dibandingkan dengan Brachiaria humidicola. Sedangkan, komponen batang tidak berbeda nyata untuk kedua jenis rumput. Hijauan pakan yang dihasilkan untuk kebutuhan pakan ruminansia, diharapkan komponen daun lebih banyak daripada komponen batang (Polakitan dan Kairupan, 2010).

\section{KESIMPULAN}

Berdasarkan hasil penelitian dapat disimpulkan bahwa kedua jenis rumput uji membutuhkan perlakuan unsur makro NPK lengkap untuk mendapatkan hasil dengan komponen daun lebih tinggi.

\section{DAFTAR PUSTAKA}

Anis. S.D. 2011a. Karakteristik pertumbuhan dan perkembangan vegetative rumput $B$. Humidicola pada lahan tegakan kelapa. Laporan Topik Khusus. Program Studi Agronomi. Sekolah Pascasarjana, Institut Pertanian Bogor.

Aryanto dan D. Polakitan, 2009. Uji Produksi Rumput Dwarf (Pennicetum purpureum cv.Mott). Jurnal ilmiah,
Balai Pengkajian Teknologi Pertanian Sulawesi Utara, J1. Kampus Pertanian Kalasey.

Gillen, R.L and A.L.Ewing, 1992. Leaf development on native blustem grasses in relation to degree-day accumulation. J. Range Manage 45 : $200-204$.

Kaligis, D.A and C. Sumolang 1990. Forage species for coconut plantation in North Sulawesi. In: Forage Plantation Crops: ed: H.M. Shelton and W.W. Stur. ACIAR Proc. No. 32

Manske, L and T.C. Caesar-TonThat. 2002. Grazing Management Effects on Rhizophere Fungi. Annual Report 2002. Dickinson Research Extention center. Dickinson, ND 58601.

Polakitan. D dan A. Kairupan, 2009. Pertumbuhan dan Produktivitas Rumput Gajah Dwarf (Pennisetum purpureum cv.Mott) pada umur Potong Berbeda, http://peternakan.litbang.deptan.go.id/ fullteks/jitv113-5.pdf. Diunduh tanggal, 10 april 2013.

Warembourg, F.R and D.H. Esterlrich, 2000. Towards a better understanding of Carbon flow in the rhizophere: a time-dependent approach using carbon-14. Biol. Fertil Soils 30 : 528534

Whiteman, P. C. 2001. Tropical Pasture Science Published in The United States by Oxford University Press, Newyork 